\title{
Assessment of Morphometric Characteristics of Wadi Al-Shumar Catchment in Jordan
}

\author{
Zeyad Makhamreh*, Mohammad Al-Hawary, Samih Odeh \\ The University of Jordan, School of Arts, Geography Department, Amman, Jordan \\ Email: ${ }^{\star}$ z.makhamreh@ju.edu.jo
}

How to cite this paper: Markhamreh, Z., Al-Hawary, M. and Odeh, S. (2020) Assessment of Morphometric Characteristics of Wadi Al-Shumar Catchment in Jordan. Open Journal of Geology, 10, 155-170. https://doi.org/10.4236/ojg.2020.102009

Received: January 4, 2020

Accepted: February 17, 2020

Published: February 20, 2020

Copyright $\odot 2020$ by author(s) and Scientific Research Publishing Inc. This work is licensed under the Creative Commons Attribution International License (CC BY 4.0).

http://creativecommons.org/licenses/by/4.0/

(c) (i) Open Access

\begin{abstract}
The Geographic information system and Aster DEM data with $30 \mathrm{~m}$ resolution have been used for the derivation of the morphometric parameters of the Al-Shumar watershed in Jordan. It is an area of $330 \mathrm{~km}^{2}$, and it has seven sub-catchments. The drainage pattern of the watershed shows a dendritic and parallel pattern, with a drainage density value of $1.49-1.85 \mathrm{~km} / \mathrm{km}^{2}$. The bifurcation value of the sub-watersheds varies from 2.679 to 4.434 , which reveals homogeneous drainage networks that formed on rocks when the influence of geologic structure on the stream network is negligible. The form factor value is near the rectangular shape except for the Al-Shiah and Al-Zarnouk watershed, these values are close to the circular shape and therefore they are vulnerable to flood risk in case of frequent rainfall events. The results are important in understanding the process of rainfall-runoff in Dryland environments and in adaptation of suitable water management practices on the sub-catchment level.
\end{abstract}

\section{Keywords}

River Morphometry, DEM, GIS Analysis, Dryland Regions, Jordan

\section{Introduction}

The water catchment is a space of ground where its inner water draws toward all lands reaching the lowest point known as drain [1]. A Morphometric characteristic description is the most common technique in basin analysis and it refers to the quantitative evaluation of the earth surface landform [2]. Morphometry is the measurement of the configuration of the earth's surface, shape and landforms dimensions using mathematical models [3]. Studying the morphometric features of catchments is very important; in order to investigate the metric measurements of the water network and hydrological properties of the catchment 
[4]. The geologic and climatic properties are considered the most effective agents in determining the fluvial pelvic; therefore, it is important to understand the hydrologic and geologic structures of the basin [5] [6]. It is worth noting that modern practical studies point to the importance of investigating quantitative hydrologic studies to predict the natural hazards that may affect watersheds such as water floods and pollution, in addition to improving effective methods for reducing the environmental damage as well as deducing social and economic losses [7] [8].

Many countries suffer from water scarcity and they concentrate on developing strategies to conserve water in pelvises and catchments in efficient ways [9] [10]. Thus, these countries can draw developmental plans that are suitable to the produced volume of water [11]. Digital elevation models (DEM) are used to derive the morphometric parameters of fluvial pelvic like the characteristics of slope, flow and drainage system [12]. Therefore, managing natural sources and conserving soil from erosion are considered the greatest interests of quantitative studies of draining pelvises [13]. Considering the hydrologic manner of water inside a fluvial pelvic, it should suit human uses of water and the water management system of the watershed management.

In the last years, there have been many geomorphometric analyses of floods, soil erosion, morphotectonic, and limnology [14]-[19]. The development of geographic information systems and space technologies, digital elevation models are now mainly used in geo-morphometric analyses [20] [21] [22]. Spatial analysis technique is used to understand and evaluate the various aerographic shapes that form pelvic conditions and which directly affect the quantitative results of the morphometric features of drainage pelvis [23] [24]. It helps in an Authigenic analysis that is related to pelvic characteristics and the prediction of the hydrological manner of water catchment.

Furthermore, the novelty of this research is taking into consideration the effects of natural characteristics that form the morphometric characteristics of the basin and the influences on the floods' vulnerability in the catchments level [25]. This study aims to derive the morphometric properties of Wadi Al-Shumar using GIS techniques in order to improve the watershed management and maintain the sustainability of natural resources in Jordan.

\section{Study Area}

Wadi Al-Shumar catchment is located in north of Jordan within Longitude $\left(35^{\circ} 55^{\prime} 0^{\prime \prime}-36^{\circ} 6^{\prime} 0^{\prime \prime}\right)$ E and Latitudes of $\left(32^{\circ} 20^{\prime} 0^{\prime \prime}-32^{\circ} 42^{\prime} 0^{\prime \prime}\right) \mathrm{N}$, with a total area of $330 \mathrm{~km}^{2}$ as shown in Figure 1.

In general, the climate is classified as a semi-arid Mediterranean type with a rainfall amount that does not exceed $(350-400) \mathrm{mm}$ /year and it is characterized by significant variations within the catchment. Elevation of the catchment ranges from $1018 \mathrm{~m}$ in the southern part to $262 \mathrm{~m}$ in the northern part.

This difference in topography is reflected on climatic characteristics of the 


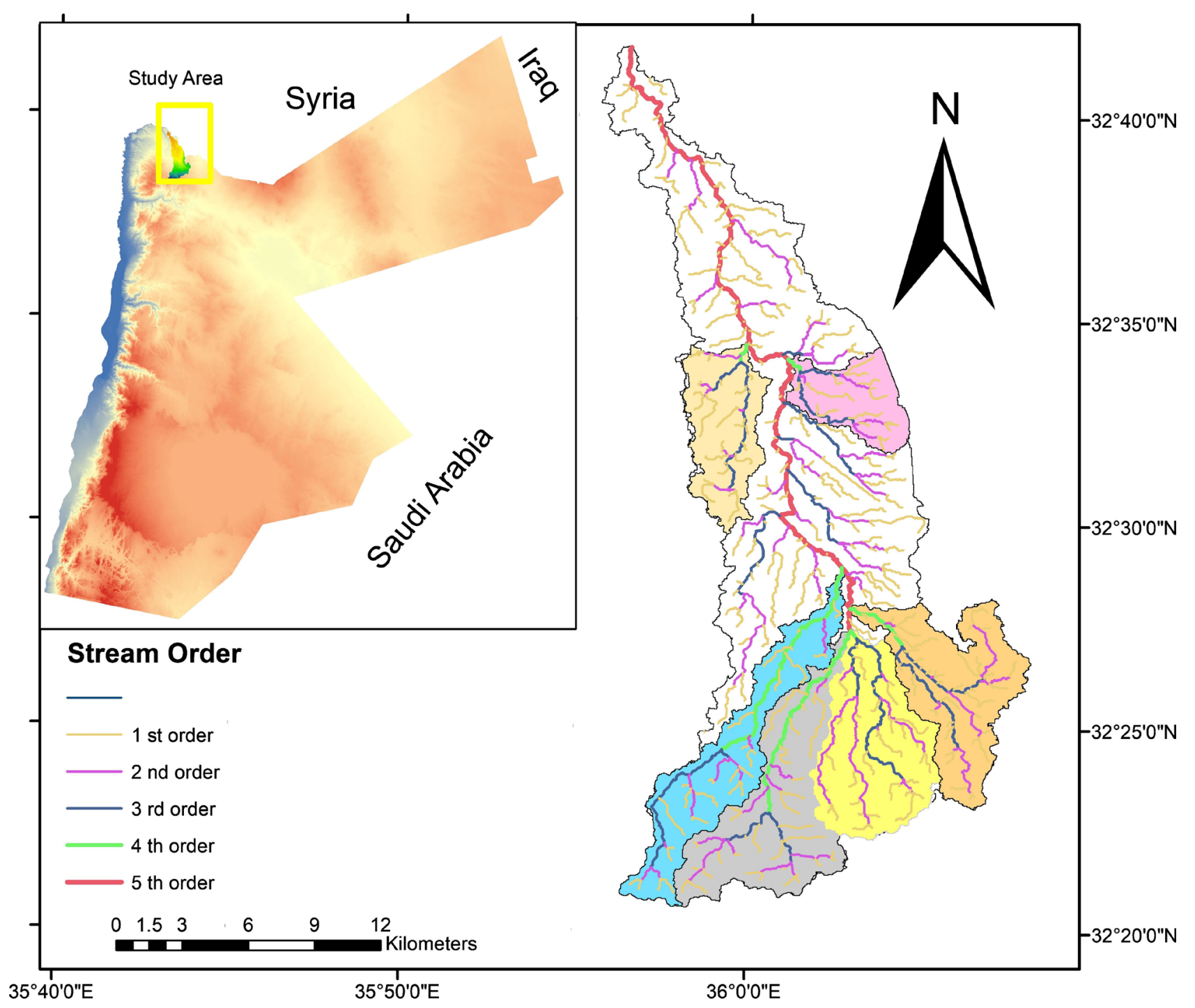

Figure 1. Location map of the Wadi Al-Shumar catchment in Northern Jordan [26].

catchment in the way that the northern part had always received more rainfall than the southern part. Accordingly, the study area is characterized by a great diversity of soil types, biodiversity, and land use pattern and vegetation density.

\section{Methods}

The statistical analysis of pelvic variables was investigated to describe the relationship between the morphometric variables and the ground surface composition on a sub-catchment basis. This enables understanding the ground constitutions of the water pelvis including pelvis boundary, rock types, geologic constitution, soil types, porosity size and the enforceability of the rock.

The catchment and sub-catchment boundary were delineated based on the topographic maps of 1:25,000 scale, and the DEM derived from Advanced Space Borne Thermal Emission and Reflection (ASTER) images with resolution of 30 $\mathrm{m}$. The hydrologic analysis is processed using GIS to derive the slope degree, as- 
pect, flow direction, drainage density, drainage rank, and the pattern of flow in the catchment. All of these analyses are carried out on the main catchment of Wadi Al-Shumar and its sub-catchments to determine its morphometric and hydrological characteristics.

The spatial characteristics of the morphometric variables of the catchment and sub-catchments are investigated, these include linear, areal and relief aspects. These variables are related to catchment length, total length of waterways, and to the average length of watercourses. In addition, the correlation between the morphometric characteristics of the river drainage catchment and its sub-catchments was investigated using statistical techniques for morphometric variables, which are represented, by the mathematical equations for the linear, areal, and relief parameters. The previous parameters were analyzed according to the equations shown in Table 1.

Detailed description of the related morphological network analysis consists of a number of waterways, length of the watercourses, and the rate of the ratio of

Table 1. The morphometric variables that were measured in this study [22] [27].

\begin{tabular}{|c|c|c|c|}
\hline & Morphometric parameters & Methods & References \\
\hline \multirow[t]{8}{*}{ Linear aspects } & number of Stream $(\mathrm{Nu})$ & Hierarchical ordering & {$[28]$} \\
\hline & Stream order $(u)$ & Hierarchical Rank & {$[28]$} \\
\hline & Stream length $(\mathrm{Lu})$ & Length of the stream & [29] \\
\hline & Mean stream length $(\mathrm{Lm})$ & $\mathrm{Lm}=\mathrm{Lu} / \mathrm{Nu}$ & [29] \\
\hline & Stream length ratio $(\mathrm{Rl})$ & $\begin{array}{l}\mathrm{Rl}=\mathrm{Lu} / \mathrm{L}(\mathrm{u}-1) \text {, where } \mathrm{Lu} \text { is stream length order } \mathrm{u} \text { and } \mathrm{L}\left(\mathrm{u}_{-} 1\right) \text { is stream segment } \\
\text { length of the next lower order }\end{array}$ & [29] \\
\hline & Bifurcation ratio $(\mathrm{Rb})$ & $\begin{array}{l}\mathrm{Rb}=\mathrm{Nu} / \mathrm{N}(\mathrm{u}-1) \text {, where } \mathrm{Nu} \text { is number of streams of any given order and } \mathrm{N}(\mathrm{u}-1) \text { is } \\
\text { number in the next higher order }\end{array}$ & [29] \\
\hline & perimeter $(\mathrm{P})$ & Perimeter of the watershed in $(\mathrm{km})$ measured by GIS & [30] \\
\hline & Basin length (lb) & Length of watershed $(\mathrm{Km})$ measured by GIS & [29] \\
\hline \multirow[t]{7}{*}{ Areal aspects } & Drainage density (Dd) & $\mathrm{Dd}=\mathrm{L} / \mathrm{A}$, where $\mathrm{L}$ is total stream length, $\mathrm{A}$ is area of the watershed & [29] \\
\hline & Stream frequency $(\mathrm{Fs})$ & $\mathrm{Fs}=\mathrm{N} / \mathrm{A}$, where $\mathrm{N}$ is the total number of streams and $\mathrm{A}$ is area of the watershed & [29] \\
\hline & Drainage texture $(\mathrm{Dt})$ & $\mathrm{T}=\mathrm{Dd} 9 \mathrm{Fs}$ & {$[31]$} \\
\hline & Lemniscate Ratio (K) & $\mathrm{k}=\mathrm{L} 2 / 4 \mathrm{~A}$ & {$[31]$} \\
\hline & Form factor (Rf) & $\mathrm{Ff}=\mathrm{A} / \mathrm{Lb} 2$ & [29] \\
\hline & Circularity ratio $(\mathrm{Rc})$ & $\mathrm{Rc}=4 \mathrm{pA} / \mathrm{P} 2$ & {$[30]$} \\
\hline & Elongation ratio $(\mathrm{Re})$ & $\mathrm{Re}=2 \mathrm{H}(\mathrm{A} / \mathrm{p}) / \mathrm{Lb}$, where $\mathrm{A}$ is area of the watershed, $\mathrm{p}$ is 3.14 and $\mathrm{Lb}$ is basin length & {$[31]$} \\
\hline \multirow[t]{5}{*}{ Relief aspects } & Basin relief $(\mathrm{R})$ & $\begin{array}{l}\mathrm{R}=\mathrm{H}-\mathrm{h} \text {, where } \mathrm{H} \text { is maximum elevation and } \mathrm{h} \text { is Minimum elevation within the } \\
\text { basin }\end{array}$ & [31] \\
\hline & Relief ratio (Rr) & $\mathrm{Rr}=\mathrm{R} / \mathrm{Lb}$ & {$[32]$} \\
\hline & Ruggedness number (Rn) & $\mathrm{Rn}=\mathrm{R} 9 \mathrm{Dd}$ & [33] \\
\hline & Dissection index (Dis) & Dis $=R / R a$, where $R=$ Relative relief and $\mathrm{Ra}$ is absolute relief & {$[34]$} \\
\hline & Drainage intensity (Di) & $\mathrm{Di}=\mathrm{Fs} / \mathrm{Dd}$ & {$[35]$} \\
\hline
\end{tabular}


the diffusion, discharge density, river frequency, and the length of water flow. It includes also parametric descriptions of the pelvis constitutions such as semicalcification, degree of rigidity, pelvic texture, and vertical depth. The total variables consist of semi-flattening, integration coefficient, form factor, semi-rotation, and semi-elongation and elongation ratio.

\section{Result and Discussion}

The morphometric investigation incorporates measurement and mathematical analysis of the area, altitude, volume, slope, as well as profiles of the land and drainage basin characteristics of the catchment area concerned. The water network of basins is developed because of rock composition, climate determinants and active structural movements under previous and current environments. The differences in the formal patterns of the water network from one sub-catchment to another within the catchment are reflected in the characteristics and values of the morphometric variables of the sub-catchments. The drainage pattern of the watershed shows a dendritic and parallel pattern as given in Figure 2, which represents a tree drainage that spreads over the northern, eastern and southern region of the pelvis, and which is mainly associated with the presence of cracks in the catchment.

This section describes the main results of the morphometric variables analysis which includes network patterns, perimeter, catchment length, stream order, number of streams, length of stream, stream length ratio, bifurcation ratio, drainage density, drainage texture, stream frequency, elongation ratio, lemniscate ratio, form factor, basin relief, relief ratio, ruggedness number and dissection index.

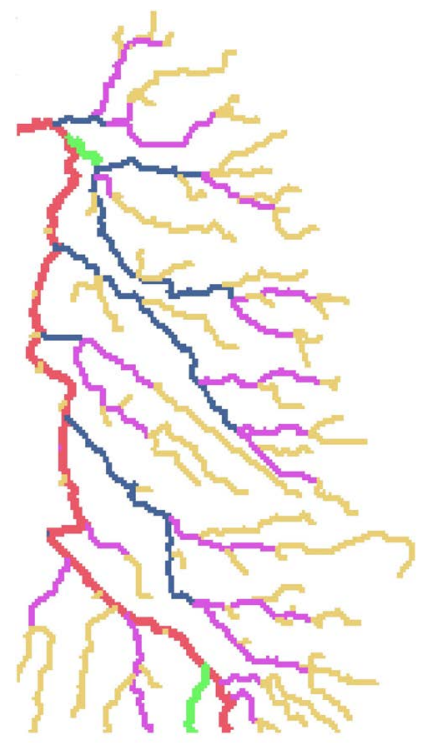

(a)

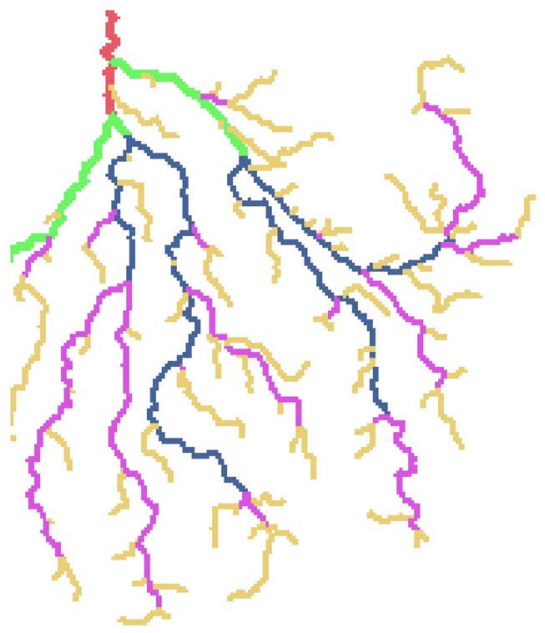

(b)

Figure 2. The drainage pattern of the watershed shows a parallel shape (a) and dendritic shape (b) pattern. 


\subsection{Linear Aspects}

Wadi Al-Shumar catchment was divided into seven sub-catchments as given in Figure 3; these are Wadi Al-Shumar, Braiqa, Mashqam, Zarnouk, West of Ramtha, Al-Shiah, and Al-Mashro.

Analysis of the linear aspects in this study includes the Area (A), Perimeter (P), Basin Length (Lb) and the number of stream. Table 2 shows the linear aspects values of the catchments and the sub-catchments. The results show that

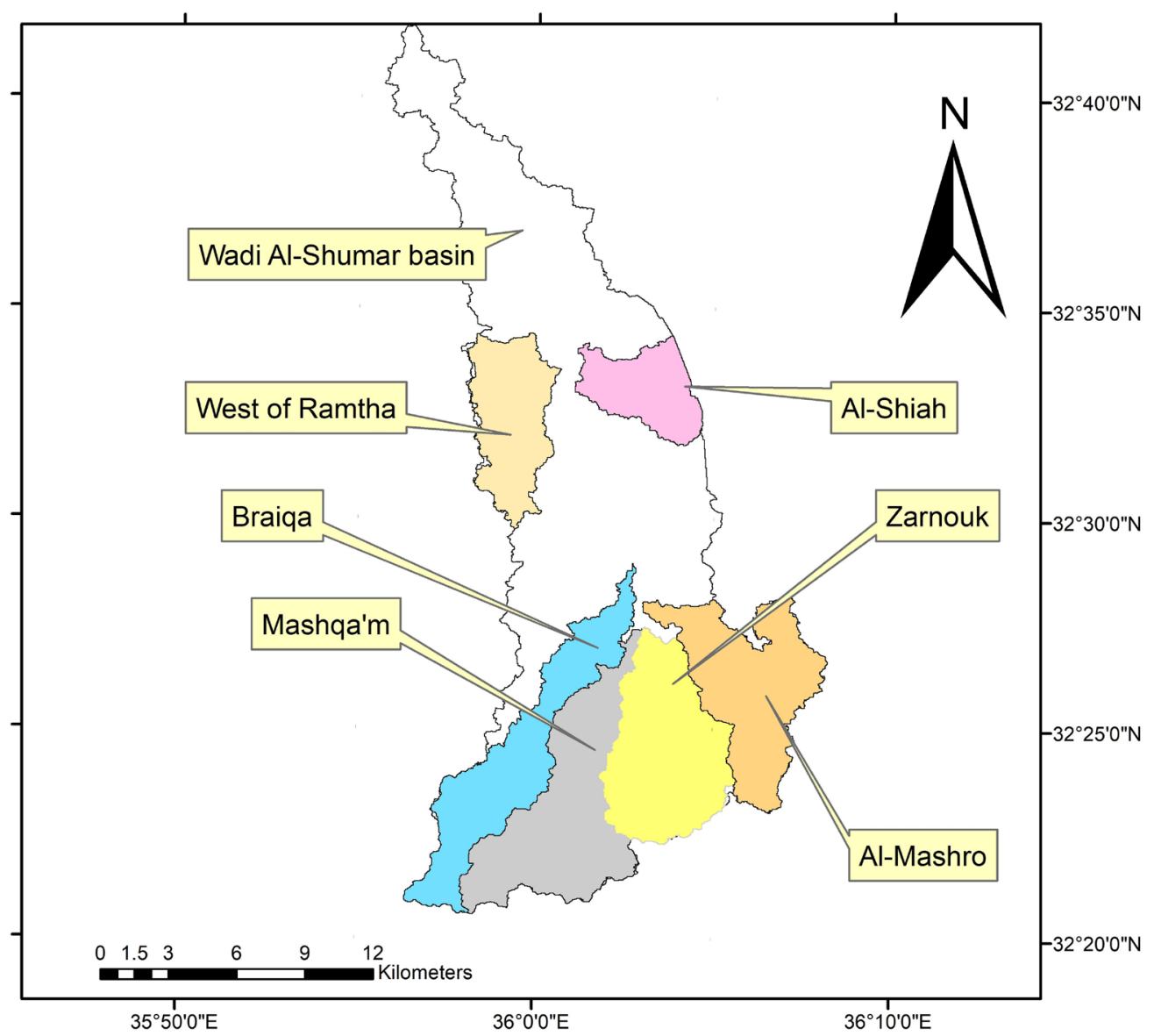

Figure 3. Wadi Al-Shumar main catchment and sub-catchments.

Table 2. The linear aspects values of the catchment and the sub-catchments.

\begin{tabular}{ccccc}
\hline $\begin{array}{c}\text { Name of watershed \& } \\
\text { sub-watershed }\end{array}$ & $\begin{array}{c}\text { Perimeter (p) } \\
\mathbf{k m}\end{array}$ & Area (A) $\mathrm{Km}^{2}$ & $\begin{array}{c}\text { Basin Length } \\
(\mathrm{Lb})\end{array}$ & $\begin{array}{c}\text { Number of } \\
\text { Stream (NU) }\end{array}$ \\
\hline Wadi Al-Shumar basin & 187.09 & 329.75 & 37.6 & 489 \\
West of Ramtha & 38.017 & 22.536 & 8.63 & 40 \\
Al-Shiah & 27.122 & 15.846 & 6.558 & 29 \\
Braiqa & 67.284 & 34.014 & 17.606 & 49 \\
Mashqa'm & 58.301 & 40.019 & 11.604 & 59 \\
Zarnouk & 39.64 & 36.998 & 9.601 & 62 \\
Al-Mashro & 54.302 & 34.799 & 14.665 & 59 \\
\hline
\end{tabular}


the area of sub-catchments ranges from 15 to $329 \mathrm{~km}^{2}$, while the perimeter of the sub-catchments ranges from 27 to $187 \mathrm{~km}$. These relationships indicate a significant difference between shape properties on the sub-catchments level. The basin length is the horizontal distance between the upstream and downstream points of the metric basin [33]; in this study, the length of the main valley in Al-Shumar catchment is $37.6 \mathrm{~km}$. On the other hand, the ponds' length for other sub-catchments ranges from $6.5 \mathrm{~km}$ in Wadi Al-Shayyah to $14.6 \mathrm{~km}$ in Wadi Mashqum sub-catchment.

Stream order and number $(\mathrm{Nu})$ is defined as a measure of the position of a stream in the hierarchy of tributaries. The classifications of streams are being useful indicators of stream size, discharge and drainage area [28]. The concourse of tributaries of the second level cause the formation of a tributary of the third rank, while the tributaries begin to form with each other at the confluence of the small water channels building a higher river tributary than the rank [33]. High number of tributaries in the catchment are attributed to the amount of precipitation and low-vegetation density in the river catchment environment.

The river tributaries are used as a logical indication of the formation related to river tributaries of large river ranks [29]. The analysis of the DEM data of the study area revealed that the total number of river canals of the main study catchment was 489 strands of different ranks, which indicates that the study basin is classified as a fifth level basin. While the number of streams of the first class is 321 tributaries which accounted for $65.6 \%$ of the total number of water network ways, it is noticeable that the number of waterways decreases by the river level as shown in Figure 4.

Stream length $(\mathrm{Lu})$ indicates the contributing area of the basin for a given order [29]. The length of stream segments is high for first order streams and decreases as the stream order increases. The total length of the catchment tributaries is $521 \mathrm{Km}$, with the length of first-class tributaries reaching $8.18 \mathrm{~km}$, the second reaching $0.838 \mathrm{~km}$, the third reaching $4 \mathrm{~km}$ and the fourth is $4.67 \mathrm{~km}$, while the fifth is $37.78 \mathrm{~km}$.

The length of the lower stratum is $50.4 \%$ of the length of the tributaries, with

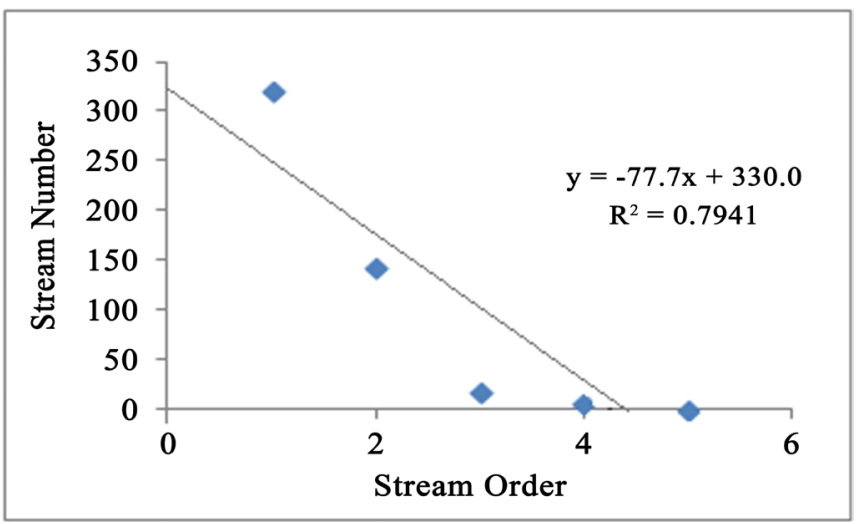

Figure 4. The relationship between the number of streams and stream orders in Al-Shumar catchment. 
$23 \%$ for the third, $13.9 \%$ for the fourth, $5.3 \%$ for the fifth, and $7.2 \%$ for the tributaries. This means that the tributaries of the lower levels are of low length values as shown in Figure 5, and they increase with increasing the level of rank that they represent.

Stream length ratio ( $\mathrm{RL}$ ) is the ratio of the average length of the one order to the next lower order of the stream segments [29]. The stream length ratio, among (7) sub-watersheds, varies from 0.456 to 1.384 . The fourth-level ponds were between 34 and 1.902. This difference in values explains the change in the falling value of the basins. The analysis shows that the level of relief increases on the southern side of the basin and it decreases as moving towards the northern direction, which leads to an increase in the soil erosion severity in the basin.

Bifurcation ratio $(\mathrm{Rb})$ is defined according to [36] as a ratio of the number of streams of a given order $(\mathrm{Nu})$ to the number of streams of the next higher order $(\mathrm{Nu}+1)$. In this study, the bifurcation ratio fluctuates in Wadi Al-Shumar basin from 2.2 to 7.9 , but the average bifurcation ratio $(\mathrm{Rbm})$ is 3.71 . On the other hand, the $\mathrm{RB}$ ratio of the sub-catchments ranges from 1.56 to 11.5 , and the $\mathrm{Rbm}$ value ranges between 2.679 and 4.434. According to the above results, one of the fourth-level basins has emerged from narrowing, which has a class value of RBM up to 3 - 5. This means that this time is susceptible to rapid seasonal floods, while other basins are geologically homogenous and are still vertically and horizontally capable of absorbing movements.

Under these conditions, the flash floods, which may suddenly form in arid and semi-arid regions, can be considered as one of the most dangerous geomorphological hazards to human constructions. It forms because of rapid watercourses with a relatively large hierarchical classification, which leads to high soil erosion rate in the basin and a great loss of plant and animal wealth [3].

\subsection{Areal Aspects}

Analysis of the areal aspects includes the drainage density (Dd), Drainage texture

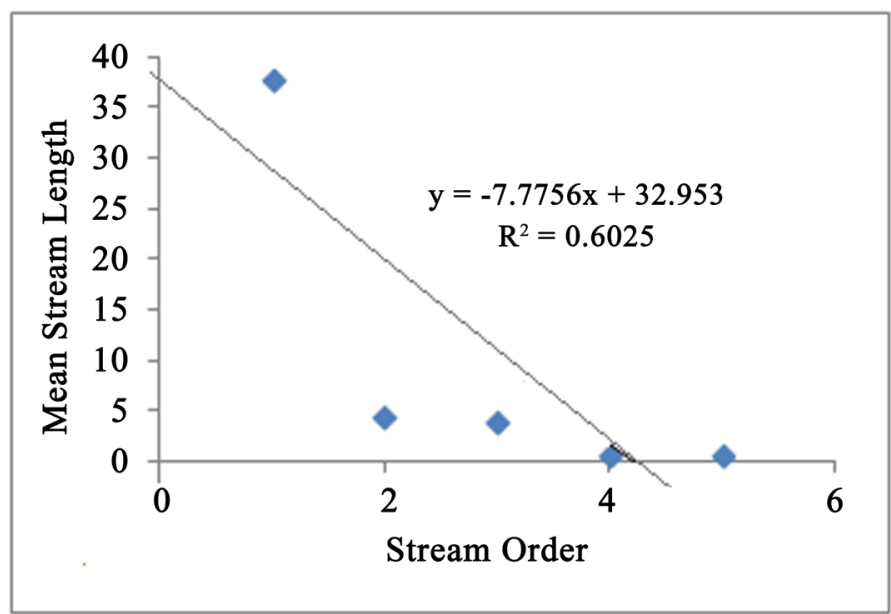

Figure 5. The relationship between the stream lengths and stream orders in Al-Shumar catchment. 
(Dt), Stream frequency (Fs), Elongation ratio (Re), Lemniscate Ratio (K), and Form factor (Rf). Table 3 shows the areal aspects of values of the catchments and the sub-catchments.

The drainage density (Dd) is a measure of total stream length over the total area in a given basin [36]. It is affected by the factors that control the characteristic of watershed length and it is one of the most significant morphometric variables that explains the volume of water flow within the main and sub-tributaries of the basin [37]. Slope factor, soil permeability and resistance of surface materials are the main factors influencing this variable. Kant et al. classify the draining density value into three categories, these are, the low, medium and high classes [38]. In this study, the drainage density value of the catchments and sub-catchments ranges between 1.49 and 1.85 as shown in Table 3 . These values are classified in the low discharge ponds.

The drainage texture (Dt) is the relative spacing of the streams in a unit area along a linear horizontal distance between water tributaries of the basin [31] [39]. It depends on the geological structure, soil types, vegetation cover, relief, infiltration rate and the amount of precipitation in the basin [29] [40].

The value of this variable is explained by the structure and nature of the river sediments that scattered in the estuary. According to Smith's classification, the value of sediment thickness can be summarized as following: Less than 2 corresponds to very rough, 2 - 4 corresponds to rough, $4-6$ is average roughness, 6-8 is fine, while more than 8 correspond to very fine. In this study, the value of the pelvic texture in Wadi Al-Shumer basin is 2.6, which is classified as rough, while the rest of the sub-basins ranged between 0.73 and 1.56 , which were classified as very rough.

Stream frequency (Fs) is the ratio of waterways in the river basin to the basin area, where the variable explains the ability of falling water to cause surface water runoff in the structure of the basin [41]. In addition, this value can explain the percentage of water that leaked to the soil profile to enhance groundwater resources. In this study, the river recurrence value in Wadi Al-Shumar basin was 1.4 , while in the other sub-basins it fluctuated between 1.44 and 1.83 . The relatively

Table 3. The areal aspects values of the catchments and the sub-catchments.

\begin{tabular}{ccccccc}
\hline $\begin{array}{c}\text { Name of watershed \& } \\
\text { sub-watershed }\end{array}$ & $\begin{array}{c}\text { Drainage } \\
\text { density } \\
(\mathrm{Dd})\end{array}$ & $\begin{array}{c}\text { Drainage } \\
\text { texture } \\
(\mathrm{Dt})\end{array}$ & $\begin{array}{c}\text { Stream } \\
\text { frequency } \\
(\mathrm{Fs})\end{array}$ & $\begin{array}{c}\text { Elongation } \\
\text { ratio }\end{array}$ & $\begin{array}{c}\text { Lemniscate } \\
\text { ratio (K) }\end{array}$ & $\begin{array}{c}\text { Form } \\
\text { factor } \\
\text { (Rf) }\end{array}$ \\
\hline Wadi Al-Shumar basin & 1.58 & 2.61 & 1.48 & 0.54 & 1.07 & 0.23 \\
West of Ramtha & 1.49 & 1.05 & 1.77 & 0.62 & 0.83 & 0.30 \\
Al-Shiah & 1.85 & 1.85 & 1.83 & 0.68 & 0.68 & 0.37 \\
Braiqa & 1.57 & 0.73 & 1.44 & 0.37 & 2.28 & 0.11 \\
Mashqa'm & 1.53 & 1.01 & 1.47 & 0.49 & 1.34 & 0.19 \\
Zarnouk & 1.61 & 1.56 & 1.68 & 0.71 & 0.62 & 0.40 \\
Al-Mashro & 1.60 & 1.09 & 1.70 & 0.57 & 0.97 & 0.26 \\
\hline
\end{tabular}


low values that can be explained due to the existence of the basin under semi-arid conditions and receive low amounts of precipitation, which is the main factor influencing the stream frequency.

Elongation ratio $(\mathrm{Re})$ is the ratio of diameter $(\mathrm{D})$ of a circle of the same area as the basin (A) to the basin length (L) [32] [33]. It reflects the variations of geological and climatic composition of the basin structure, and the presence of steep slopes in the catchment [30], and varies according to the age of the basin [42]. The elongation ratio varies from zero, which indicates a highly elongated basin with low relief, to a ratio of one, that point out to the presence of a circular basin with high relief [43] [44]. The higher value of elongation ratio of a basin the higher the indication of an active denudation process that is accompanied by high infiltration capacity and low run-off in the basin. On the other hand, a low Re value is indicative of higher elevation of the basin, a susceptible-to-high head-ward erosion along with indications of tectonic lineaments [45]. The elongation value of Wadi Al-Shumar basin ranges from 0.54 to 0.47 , while the rest of the ponds range from 0.37 to 0.71 . This indicates that these ponds are closer to the rectangular shape than the circular shape; therefore, Al-Shumar valley is classified as a rectangular shape and the rest of the ponds are classified as elongated and very elongated.

Lemniscate Ratio $(\mathrm{K})$ value varies between 0 - 1 ; it is used to facilitate the interpretation of the life stage and the erosion cycle of the basin [31]. In this study, the value of $\mathrm{K}$ in Al-Shumer catchment is 1.07 and ranges between $0.62-2.28$ in the rest of the sub-basins.

These results show that the sub-catchments are mostly formed the rectangle shape and they are still in the early period of its erosion cycle, which can be developed with the structure of the basin.

Form factor ( $R f)$, is the coefficient of basin shape which is associated with the area factor and the pelvic length square [41]. This form factor variable helps to predict the flood hazards and the ability of water to carry mud deposits from the upstream to the downstream position. In most of the morphometric studies, the reference value of the shape of coefficient ranges from 0.1 to 0.8 . The form factor value of the Wadi Al-Shumar catchments is 0.23 while in the rest of the sub-catchments is in the range from 0.11 to 0.40 . The form factor variable value that is close to 0.8 indicates the rotation of the basin, which causes speediness degree of exposure to the flood risk and vice versa [45]. In this study, the form factor value is near the rectangular shape except for the Shihya sub-catchment, which is equal to 0.37 and the Hernouk sub-catchment with value of 0.40 . These sub-catchments values are close to the circular shape and therefore they are vulnerable to flood risk in case of frequent rainfall events.

Analysis of the relief factor includes the basin relief $(\mathrm{Bh})$, relief ratio $(\mathrm{Rr})$, Ruggedness number (Rn), and Dissection index (Dis). Table 4 presents the relief aspects values of the catchments and the sub-catchments.

Basin relief $(\mathrm{Bh})$ variable indicates the value of the height difference between 
Table 4. The relief aspects values of the catchments and the sub-catchments.

\begin{tabular}{ccccc}
\hline $\begin{array}{c}\text { Name of watershed \& } \\
\text { sub-watershed }\end{array}$ & Basin relief (Bh) & Relief Ratio (Rr) & $\begin{array}{c}\text { Ruggedness } \\
\text { number (Rn) }\end{array}$ & $\begin{array}{c}\text { Dissection index } \\
\text { (Dis) }\end{array}$ \\
\hline Wadi Al-Shumar basin & 756 & 20.11 & 1.19 & 0.74 \\
West of Ramtha & 124 & 14.37 & 0.18 & 0.20 \\
Al-Shiah & 163 & 24.86 & 0.30 & 0.25 \\
Braiqa & 453 & 25.73 & 0.71 & 0.45 \\
Mashqa'm & 472 & 32.19 & 0.72 & 0.46 \\
Zarnouk & 352 & 36.66 & 0.57 & 0.38 \\
Al-Mashro & 239 & 20.60 & 0.38 & 0.30 \\
\hline
\end{tabular}

the lowest and the highest area in the basin structure, and it explains the similarity and differences in the spatial environment of the basin. This value relates to the geological structure, extent of rock resistance against the fragmentation processes, and to the impact on the sediments' quality (4). The steep slope is closely related to the geological structure and the ability of rocks to resist the erosion, however, the high value indicates a very steep and high erosion force [5]. In this study, the basin relief was extracted from the DEM, and the value of it is in the range from $756 \mathrm{~m}$ in the main catchment to $126 \mathrm{~m}$ in the west of Ramtha sub-catchment.

These values display that these ponds are still able of carving streams and river valleys, and able of increasing the rock carving as well.

The concept of the Relief Ratio ( $R r)$ has been introduced in the interpretation of morphometric variables by [31], as a dimensionless ratio between basin relief and basin length and widely accepted as an effective measure of gradient aspects of the watershed [46]. The relief ratio indicates the overall steepness of a drainage basin and is an indicator of the intensity of erosional processes operating on the slopes of the basin [22]. This increase in the sediments' amount is resulting from the flow of the river level horizontally and vertically; thus, ponds are added to the stage that it reaches in the current cycle. The rate of relief at Wadi Al-Shumar basin was 20.11 meters, while the lowest value in the sub-catchments was 14.37 , and the highest was 36.66 . These values indicate that there is a significant erosion force resulting from the erosion processes with a high slope value.

Ruggedness number $(\mathrm{Rn})$ is one of the morphometric variables that was obtained from the total density of the river drainage [39] [41]. This variable provides explanation of the positive relationship between the total calcification and density of drainage in the catchment. In general, the increase in the value of rationale pruning that is associated with an increase in the degree of roughening reflects the age of the erosion cycle in the catchment. The high degree of roughening means an increase in the capacity of water for soil erosion, and consequently, an increase in the river load of the sediments [24]. In this study, the degree of ruggedness was found to be 1.19 in the main catchment, while in the 
secondary ponds it ranges between 0.18 and 0.72 ; which means that Al-Shumar catchment is characterized by the value greater than (1) that represents a high roughness level. On the other hand, the other sub-catchments were classified as low-reared, and two other basins were medium-bumped. These results can be explained by the difference in the geological structures across sub-catchments, which directly affect the degree of basins roughness. Accordingly, the northern and eastern areas of the catchment were characterized as low pelvic areas and by a low bump degree.

Dissection index (Dis) is the vertical depth indication of the effective morphometric variables and which is considered an effective measure in determining water viability to make a change in the vertical depth of the river channel. The value of the (Dis) variable varies from (0 - 1); where the value of (1) shows a strong vertical setting, the value of (0) shows a weaker one. In this study, the vertical depth value was 0.74 of Wadi Al-Shumar catchment. This indicates a deep vertical depth that is directly linked to the high level of pelvic drainage and the relatively small catchment area.

These results suggest that Wadi Al-Shumar basin suffers from the exposure of the soil to erosion risk, in addition to the conclusion suggesting that the spreading risk of soil erosion is resulting from heavy rainstorms and low coverage of vegetation under semi-arid areas.

\section{Conclusion}

Watershed drainage network is an important geomorphological unit, which reflects topographic and hydrological unity. Hydrological characterization of Al-Shumar watershed and its sub-watershed revealed the importance of morphometric analysis in terrain depiction and basin evolution. In this regard, the GIS technique provided high accuracy in the mapping and the measurement of morphometric analysis. The analysis presents a medium-developed drainage network and an immature geomorphic stage in the watershed. The drainage density value indicates moderate slope terrain with sparse to dense vegetation, a higher infiltration rate, a moderate surface runoff and less dissection. The watershed and its sub-watersheds have elongated shape making them less prone to flood, lower erosion, and to sediment transport capacities. The differences in relief level results explain the dominance of the arid and semi-arid climatic environments in the study area; thus, they tend to reduce the water's ability to cause any changes in the watershed environment. The elongation variable value shows that the watershed passes through its youth stage of erosion as an increase in length, which is an occurring that was observed in the main course of the valley. This explains the vulnerability to floods in the river valley to the length of the distance traveled by water compared to the area of the river valley. The results show that the morphometric parameters are able to provide relevant information about vulnerability of the watershed for floods, and management plans. The study results can be improved by using higher resolution DEM data, which 
might have proficient means for the management of the water resources on sub-watersheds levels.

\section{Data Availability}

Some or all data, models, or analysis used during the study are proprietary or confidential in nature and are available with restrictions.

\section{Acknowledgements}

The authors acknowledge the deanship of scientific research in the University of Jordan for supplying financial support of this research. Acknowledgment is also extended for the Open Journal of Geology for cooperation and input.

\section{Conflicts of Interest}

The authors declare no conflicts of interest regarding the publication of this paper.

\section{References}

[1] Chopra, R., Dhiman, R.D. and Sharma, P.K. (2005) Morphometric Analysis of Sub-Watersheds in Gurdaspur District, Punjab Using Remote Sensing and GIS Techniques. Journal of the Indian Society of Remote Sensing, 33, 531-539. https://doi.org/10.1007/BF02990738

[2] Gavit, R.H. and Sonule, B. (2018) Morphometric Analysis of Auranga River Basin: A GIS-Based Approach. IOSR Journal of Applied Geology and Geophysics, 6, 38-43.

[3] Rai, P.K., Mohan, K., Aariza, S. and Mishra, V.N. (2017) A GIS-Based Approach in Drainage Morphometric Analysis of Kanhar River Basin, India. Applied Water Science, 7, 217-232. https://doi.org/10.1007/s13201-014-0238-y

[4] Soni, S. (2016) Assessment of Morphometric Characteristics of Chakrar Watershed in Madhya Pradesh India Using Geospatial Technique. Applied Water Science, 7, 2089-2102. https://doi.org/10.1007/s13201-016-0395-2

[5] Ebinger, C. and Scholz, C.A. (2011) Continental Rift Basins: The East African Perspective, Tectonics of Sedimentary Basins. John Wiley and Sons, Ltd., Hoboken, 183-208. https://doi.org/10.1002/9781444347166.ch9

[6] Prakash, K., Chaubey, K., Singh, S., Mohanty, T. and Singh, C.K. (2017) Morphometric Analysis of the Satna River Basin, Central India. Indian Journal of Geomorphology, 22, 41-60.

[7] Magesh, N.S., Chandrasekar, N. and Soundranayagam, J.P. (2011) Morphometric Evaluation of Papanasam and Manimuthar Watersheds, Part of Western Ghats. Tirunelueli District, Tamil Nadu, India: A GIS Approach. Environmental Earth Sciences, 64, 374-381. https://doi.org/10.1007/s12665-010-0860-4

[8] Patel, D., Gajjar, C. and Srivastava, P. (2013) Prioritization of Malesari Mini-Watersheds through Morphometric Analysis: A Remote Sensing and GIS Perspective. Environmental Earth Sciences, 69, 2643-2656. https://doi.org/10.1007/s12665-012-2086-0

[9] Hlaing, K., Haruyama, S. and Aye, M. (2008) Using GIS Based Distributed Soil Loss Modeling and Morphometric Analysis to Prioritize Watersheds for Soil Conservation in Bago River Basin of Lower Myanmar. Frontiers of Earth Science in China, 2, 
465-478. https://doi.org/10.1007/s11707-008-0048-3

[10] Abdallah, F., El Shamy, I., Bamousa, A., Mansour, A., Mohamed, A. and Tahoom, M. (2014) Flash Floods and Groundwater Recharge Potentials in Arid Land Alluvial Basins, Southern Red Sea Coast, Egypt. International Journal of Geosciences, 5, 971-982. https://doi.org/10.4236/ijg.2014.59083

[11] Singh, P., Gupta, A. and Singh, M. (2014) Hydrological Inferences from Watershed Analysis for Water Resource Management Using Remote Sensing and GIS Techniques. The Egyptian Journal of Remote Sensing and Space Science, 17, 111-121. https://doi.org/10.1016/j.ejrs.2014.09.003

[12] Burbank, D. and Anderson, R. (2011) Tectonic Geomorphology. John Wiley and Sons, Hoboken, 480 p. https://doi.org/10.1002/9781444345063

[13] Malik, M.I., Bhat, M.S. and Kuchay, N.A. (2011) Watershed Based Drainage Morphometric Analysis of Lidder Catchment in Kashmir Valley Using Geographical Information System. Recent Research in Science and Technology, 3, 118-126.

[14] Magesh, N.S., Jitheshlal, K.V., Chandrasekar, N. and Jini, K.V. (2013) Geographical Information System-Based Morphometric Analysis of Bharathapuzha River Basin, Kerala, India. Applied Water Science, 3, 467-477. https://doi.org/10.1007/s13201-013-0095-0

[15] Ibrahim Batis, K. and Ahmed, S.A. (2014) Evaluation of Morphometric Parameters a Comparative Study from Cartosat DEM, SRTM and SOI Toposheet in Karabayyanahalli Sub-Watershed, Karnataka. International Journal of Research, 11, 679-688.

[16] Yunus, A.P., Oguchi, T. and Hayakawa, Y.S. (2014) Morphometric Analysis of Drainage Basins in the Western Arabian Peninsula Using Multivariate Statistics. International Journal of Geosciences, 5, 527-539. https://doi.org/10.4236/ijg.2014.55049

[17] Babu, K.J., Sreekumar, S. and Aslam, A. (2014) Implication of Drainage Basin Parameters of a Tropical River Basin of South India. Applied Water Science, 6, 67-75. https://doi.org/10.1007/s13201-014-0212-8

[18] Sharma, C.S., Mishra, A. and Panda, S.N. (2014) Assessing Impact of Flood on River Dynamics and Susceptible Regions: Geomorphometric Analysis. Water Resources Management, 28, 2615-2638. https://doi.org/10.1007/s11269-014-0630-2

[19] Taylor, P., Bhatt, S. and Ahmed, S.A. (2014) Morphometric Analysis to Determine Floods in the Upper Krishna Basin Using Cartosat DEM. Geocarto International, 29, 878-894. https://doi.org/10.1080/10

[20] Abdel-Lattif, A. and Sherief, Y. (2010) Morphometric Analysis and Flash Floods of Wadi Sudr and Wadi Wardan, Gulf of Suez, Egypt: Using Digital Elevation Model. Arabian Journal of Geosciences, 5, 1-15. https://doi.org/10.1007/s12517-010-0156-8

[21] Aadil Hamid, R.A.H. (2013) Application of Morphometric Analysis for Geo-Hydrological Studies Using Geo-Spatial Technology: A Case Study of Vishav Drainage Basin. Hydrology: Current Research, 4, Article ID: 1000157. https://doi.org/10.4172/2157-7587.1000157

[22] Prasannakumar, V., Vijith, H. and Geetha, N. (2013) Terrain Evaluation through the Assessment of Geomorphometric Parameters Using DEM and GIS: Case Study of Two Major Sub-Watersheds in Attapady, South India. Arab Journal of Geosciences, 6, 1141-1151. https://doi.org/10.1007/s12517-011-0408-2

[23] Thomas, J., Joseph, S., Thrivikramji, K., Abe, G. and Kannan, N. (2012) Morphometrical Analysis of Two Tropical River Basins of Contrasting Environmental Settings, the Southern Western Ghats, India. Environmental Earth Sciences, 66, 
2353-2366. https://doi.org/10.1007/s12665-011-1457-2

[24] Farhan, Y., Anbar, A., Enaba, O. and Al-Shaikh, N. (2015) Quantitative Analysis of Geomorphometric Parameters of Wadi Kerak, Jordan, Using Remote Sensing and GIS. Journal of Water Resources and Protection, 71, 456-475. https://doi.org/10.4236/jwarp.2015.76037

[25] Vijith, H. and Satheesh, R. (2006) GIS Based Morphometric Analysis of Two Major Upland Sub-Watersheds of Meenachil River in Kerala. Journal of the Indian Society of Remote Sensing, 34, 181-185. https://doi.org/10.1007/BF02991823

[26] USGS (2019) United States Geological Survey. ASTER GDEM Image Data.

[27] Markose, V., Dinesh, A. and Jayappa, K. (2014) Quantitative Analysis of Orphometric Parameters of Kali River Basin, Sothern India, Using Bearing Azimuth and Drainage (bAd) Calculator and GIS. Environmental Earth Sciences, 72, 2887-2903. https://doi.org/10.1007/s12665-014-3193-x

[28] Strahler, A.N. (1957) Quantitative Analysis of Watershed Geomorphology. Transactions, American Geophysical Union, 138, 913-938.

https://doi.org/10.1029/TR038i006p00913

[29] Horton, R. (1945) Erosional Development of Streams and their Drainage Basins; Hydrophysical Approach to Quantitative Morphology. Geological Society of America Bulletin, 56, 275-370. https://doi.org/10.1130/0016-7606(1945)56[275:EDOSAT]2.0.CO;2

[30] Miller, V. (1953) A Quantitative Geomorphic Study of Drainage Basin Characteristics in the Clinch Mountain Area, Virginia and Tennessee. Technical Report 3, Columbia University, New York, 389-402.

[31] Chorley, R., Donald, M. and Pogrzelsk, H. (1957) A New Standard for Estimating Drainage Basin Shape. American Journal of Science, 255, 138-141.

https://doi.org/10.2475/ajs.255.2.138

[32] Schumm, S. (1956) Evolution of Drainage Systems and Slopes in Badlands at Perth Amboy, New Jersey. Geological Society of America Bulletin, 64, 597-646. https://doi.org/10.1130/0016-7606(1956)67[597:EODSAS]2.0.CO;2

[33] Strahler, A.N. (1958) Quantitative Geomorphology of Drainage Basins and Channel Networks. In: Chow, V.T., Ed., Handbook of Applied Hydrology, McGraw Hill, New York, 439-476.

[34] Singh, S. and Dubey, A. (1994) Geo Environmental Planning of Watersheds in India. Chugh Publications, Allahabad, 28-69.

[35] Faniran, A. (1968) The Index of Drainage Intensity-A Provisional New Drainage Factor. Australian Journal of Science, 31, 328-330.

[36] Strahler, A.N. (1964) Quantitative Geomorphology of Drainage Basins and Channel Networks. In: Chow, V.T, Ed., Handbook of Applied Hydrology, McGraw-Hill, New York, 4-39/4-76.

[37] Farhan, Y. and Anaba, O. (2016) Watershed Prioritization Based on Morphometric Analysis and Soil Loss Modeling in Wadi Kerak (Southern Jordan) Using GIS Techniques. International Journal of Plant and Soil Science, 10, 1-18. https://doi.org/10.9734/IJPSS/2016/25321

[38] Kanth, T. and Hassan, Z. (2012) Morphometric Analysis and Prioritization of Watersheds for Soil and Water Resources Management in Wular Catchment Using Geo-Spatial Tools. International Journal of Geology, Earth and Environmental Sciences, 2, 30-41.

[39] Howard, A.D. (1967) Drainage Analysis in Geologic Interpretation, a Summation. 
American Association of Petroleum Geologists Bulletin, 51, 2246-2259. https://doi.org/10.1306/5D25C26D-16C1-11D7-8645000102C1865D

[40] Kale, V.S. and Gupta, A. (2001) Introduction to Geomorphology. Orient Longman, New Delhi.

[41] Horton, R. (1932) Drainage Basin Characteristics. Transactions, American Geophysical Union, 13, 350-361. https://doi.org/10.1029/TR013i001p00350

[42] Aldarraji Saad, A. (2013) Simplify Equation to Calculate Elongation River Basin Proposed by Schumm (1956). Al-Ustath, 2, 1-10.

[43] Bali, R., Agarwal, K., Nawaz Ali, S.N., Rastogi, S. and Krishna, K. (2012) Drainage Morphometry of Himalayan Glacio-Fluvial Basin, India-Hydrologic and Neotectonic Implications. Environmental Earth Sciences, 66, 1163-1174. https://doi.org/10.1007/s12665-011-1324-1

[44] Yadav, S.K. (2014) Morphometric Analysis of Upper Tons Basin from Northern Foreland of Peninsular India Using CARTOSAT Satellite and GIS. Geocarto International, 29, 895-914. https://doi.org/10.1080/10106049.2013.868043

[45] Reddy, G.P.O., Maji, A.K. and Gajbhiye, K.S. (2004) Drainage Morphometry and Its Influence on Landform Characteristics in a Basaltic Terrain, Central India: A Remote Sensing and GIS Approach. International Journal of Applied Earth Observation and Geoinformation, 6, 1-16. https://doi.org/10.1016/j.jag.2004.06.003

[46] Vittala, S.S., Govindiah, S. and Honne Gowda, H. (2004) Morphometric Analysis of Sub-Watersheds in the Pawagada Area of Tumkur District, South India, Using Remote Sensing and GIS Techniques. Journal of Indian Society of Remote Sensing, 32, 351-362. https://doi.org/10.1007/BF03030860 